\title{
EVOLUTION OF THE EU ORGANIC FOOD MARKET AFTER 2010
}

\author{
Laura Cătălina Țimiraş \\ "Vasile Alecsandri" University of Bacau, \\ timiras.laura@ub.ro
}

\begin{abstract}
This paper presents the evolution of the organic food market at EU level, as well as its place in the world. Market size was highlighted based on the retail sales of organic food indicator, and the consumer penetration rate of this product category was assessed by retail sales of organic food per capita. Europe is the second largest market in the world for organic food, out of the total, $91 \%$ being related to EU member states (in 2015). In the last few years, the analyzed market has seen increases in EU countries, with differences between them, both in terms of dynamics and consumption intensity (old EU members far outstripping the new ones on this indicator). Despite the positive evolution, the analyzed market remains a market with a huge potential for development, still untapped, the penetration of organic food consumption still being at a low level.
\end{abstract}

\section{Keywords}

organic food, market, European Union, retail sales, evolution

\author{
JEL Classification \\ M31, M39, C10
}

The emergence and development of organic agro-food products is a consequence of public awareness of the role that food has on the health of the population and, implicitly, of raising consumer concerns for their own health, corroborated with the government's policy of sustainable development, amid the exacerbation in the last decades of nutrition illnesses caused by inadequate nutrition.

According to EU legislation, organic (ecologic or bio) food can be labeled as organic only when at least $95 \%$ of ingredients are organic. Thus, according to Council Regulation EC No. 834/2007 on organic production and labelling of organic products, organic production is an overall system of farm management and food production that combines best environmental practices, a high level of biodiversity, the preservation of natural resources, the application of high animal welfare standards and a production method in line with the preference of certain consumers for products produced using natural substances and processes.

Certification of organic products has many advantages for both producers and consumers. Lohr, L. (1998) identifies three functions:

- guarantees to consumers that the certified product, which has no observable differences compared to non-organic products, has been grown, processed and packaged in compliance with the rules limiting or prohibiting the use of synthetic raw materials and protecting the environment;

- $\quad$ ensures producers that illegal use of the organic term (by competitors) does not deprive them of the use of premium prices and of obtaining market shares that can be generated through certified products; 
- $\quad$ increases market efficiency by reducing contradictory information along the marketing channel from manufacturer to consumer.

The evolution of the global organic food market

The global organic food market in 2015 reached more than 75.7 billion euros, representing average purchases per person of 10.3 Euros. North America is the region with the highest average spending per person, followed by Europe, but at a considerable distance (on average 100 Euros spent in North America for organic food, 33.8 Euros are allocated in Europe with the same destination). (Table 1)

Table 1. The global organic food market, in 2015, on world regions

\begin{tabular}{|l|c|c|}
\hline \multicolumn{1}{|c|}{ Region } & Retail sales (Million Euro) & $\begin{array}{c}\text { Retail sales per capita } \\
\text { (Euro / person) }\end{array}$ \\
\hline Africa & 17 & n.d \\
\hline Asia & 6255 & 1,5 \\
\hline Europe & 29781 & 36,4 \\
\hline Latin America & 31 & n.d. \\
\hline Northern America & 38539 & 107,7 \\
\hline Ocenia & 1085 & 27,6 \\
\hline World & $\mathbf{7 5 7 0 9}$ & $\mathbf{1 0 , 3}$ \\
\hline
\end{tabular}

Source: FiBL -AMI survey 2017, in Willer, Helga and Julia Lernoud (Eds.) (2017): The World of Organic Agriculture. Statistics and Emerging Trends 2017. Research Institute of Organic Agriculture (FiBL), Frick and IFOAM - Organics International, Bonn. Version 1.3 of February 20, 2017 (table 41).

According to data for 2015, the largest organic food markets in the world are: USA (holding $47.3 \%$ of the world market), followed by Germany with $11.4 \%$, France and China (under 10\%). (Figure 1)

Over time, between 2010 and 2015, the largest expansion of the organic agri-food market was recorded in China (an increase of approximately 6 times), which in fact led to its entry in 2015 among the top 5 countries in terms of analyzed market size. In the other countries at the top of the list (except for Sweden, where over 5 years the organic food market has increased more than 2 times), the increases were below $100 \%$.

Table 2. The ten countries with the largest organic food markets, in 2015 and compared to 2010

\begin{tabular}{|l|c|c|c|}
\hline \multirow{2}{*}{ Country } & \multicolumn{2}{|c|}{ Retail sales (Million Euro) } & - / + in \% in 2015 \\
\cline { 2 - 3 } & $\mathbf{2 0 1 5}$ & $\mathbf{2 0 1 0}$ & compared to 2010 \\
\hline USA & 35782 & 20155 & 77,5 \\
\hline Germany & 8620 & 6020 & 43,2 \\
\hline France & 5534 & 3385 & 63,5 \\
\hline China & 4712 & $791 *$ & $495,7 * *$ \\
\hline Canada & 2757 & 1904 & 44,8 \\
\hline United Kingdom & 2604 & 2000 & 30,2 \\
\hline Italy & 2317 & 1550 & 49,5 \\
\hline Switzerland & 2175 & 1180 & 84,3 \\
\hline Sweden & 1726 & 804 & 114,7 \\
\hline Spain & 1498 & $905 *$ & $65,5 *$ \\
\hline
\end{tabular}

Source: taking over and processing after:FiBL-AMI survey 2017, in Willer, Helga and Julia Lernoud (Eds.)

(2017): The World of Organic Agriculture, Statistics and Emerging Trends 2017. Research Institute of Organic Agriculture (FiBL), Frick and IFOAM - Organics International, Bonn. Version 1.3 of February 20, 2017 (Table 41);

FiBL survey 2012, in Willer, Helga and Lukas Kilcher (Eds.) (2012): The World of Organic Agriculture, Statistics and Emerging Trends, 2012. FiBL-IFOAM Report. Research Institute of Organic Agriculture (FiBL), Frick and IFOAM, (Table 12). 


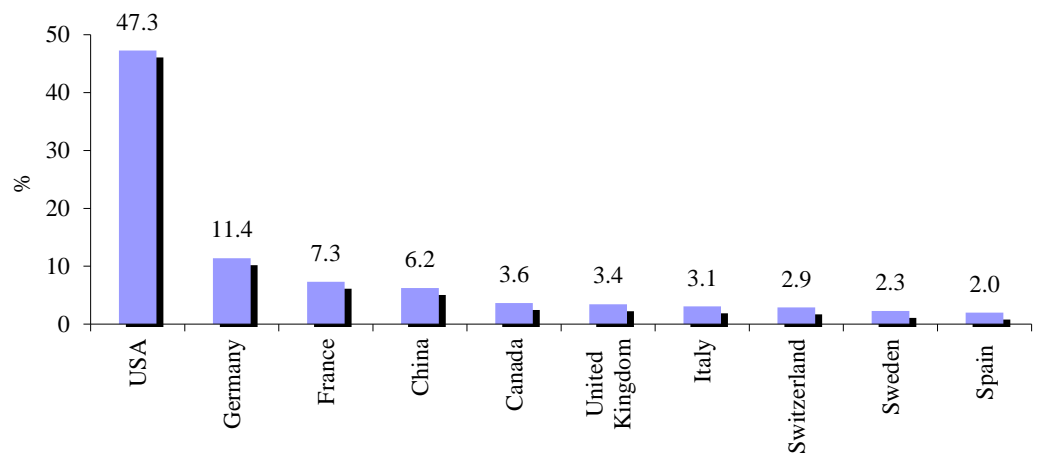

Figure 1. Total share of the ten countries with the largest organic food markets in 2015, in the global organic food market

Source: adapted after: FiBL-AMI survey 2017, in Willer, Helga and Julia Lernoud (Eds.) (2017): The

World of Organic Agriculture, Statistics and Emerging Trends 2017. Research Institute of Organic

Agriculture (FiBL), Frick and IFOAM - Organics International, Bonn. Version 1.3 of February 20, 2017

(Table 41);

Referring to average spending per capita, a more relevant indicator for assessing the level of development of organic food markets, Switzerland is the country with the highest global value (more than 25 times higher compared to the global average and over 7 times higher than the European average, according to data for 2015).

Table 3. The ten countries with the highest per capita retail sales of organic food product in 2015 and compared to 2010

\begin{tabular}{|c|c|c|c|}
\hline \multirow{2}{*}{ Country } & \multicolumn{2}{|c|}{$\begin{array}{c}\text { Retail sales per capita } \\
\text { (Euro / person) }\end{array}$} & \multirow{2}{*}{$\begin{array}{l}-/+ \text { in } \% \text { in } 2015 \\
\text { compared to } 2010\end{array}$} \\
\hline & 2015 & 2010 & \\
\hline Switzerland & 262 & 153 & 71,2 \\
\hline Denmark & 191 & 142 & 34,5 \\
\hline Sweden & 177 & 86 & 105,8 \\
\hline Luxembourg & 170 & 127 & 33,9 \\
\hline Liechtenstein & 142 & $100 *$ & $42,0 * *$ \\
\hline Austria & 127 & 118 & 7,6 \\
\hline USA & 111 & 65 & 70,8 \\
\hline Germany & 106 & 73,6 & 44,0 \\
\hline France & 83 & 52 & 59,6 \\
\hline Canada & 77 & 57 & 35,1 \\
\hline
\end{tabular}

Source: taking over and processing after: FiBL-AMI survey 2017, in Willer, Helga and Julia Lernoud (Eds.) (2017): The World of Organic Agriculture, Statistics and Emerging Trends 2017. Research Institute of Organic Agriculture (FiBL), Frick and IFOAM - Organics International, Bonn. Version 1.3 of February 20, 2017 (Table 41);

FiBL survey 2012, in Willer, Helga and Lukas Kilcher (Eds.) (2012): The World of Organic Agriculture, Statistics and Emerging Trends, 2012. FiBL-IFOAM Report. Research Institute of Organic Agriculture

(FiBL), Frick and IFOAM, (Table 12).

\section{The evolution of the EU organic food market}

By subscribing to the global trend, the size of organic food markets and average per capita spending on such products have grown in recent years in EU countries. The EU 
organic food market amounted to more than 27 billion euros (91\% of the total European market) in 2015, of which $98 \%$ belong to the old Member States.

Average spending per person has surpassed more than 5 times the world average, but this outpouring is specific only to the old members, with the countries in the old communist bloc far below average (around half of the world average). Compared to Northern America, the region where organic food has the largest penetration in consumption, the average EU consumption is only around $50 \%$.

Table 4. The EU organic food market in 2015

\begin{tabular}{|c|c|c|}
\hline Region & $\begin{array}{c}\text { Retail sales } \\
\text { (Million Euro) }\end{array}$ & $\begin{array}{c}\text { Retail sales per capita } \\
\text { (Euro / person) }\end{array}$ \\
\hline European Union, din care: & 27107 & 53,7 \\
\hline EU - 15 & 26586 & 65,9 \\
\hline The new member states & 521 & 5 \\
\hline
\end{tabular}

Source: FiBL -AMI survey 2017, in Willer, Helga and Julia Lernoud (Eds.) (2017): The World of Organic Agriculture. Statistics and Emerging Trends 2017. Research Institute of Organic Agriculture (FiBL), Frick and IFOAM - Organics International, Bonn. Version 1.3 of February 20, 2017 (table 59).

Confirming the above-mentioned idea, it is noted that in the old EU Member States, average spending per capita ranged between $€ 30$ and $€ 191$ (except for Portugal), while in the new Member States they were below $€ 30$ (Table 5). This can be explained both by economic and cultural differences between the two categories of countries, such as: the purchasing power of the population, the knowledge of consumers about the impact of diet on the state of health and the importance given to them, exigence regarding the products on the market etc.

Table 5. The organic food markets of EU countries, in 2015 and 2010

\begin{tabular}{|c|c|c|c|c|c|c|}
\hline \multirow{3}{*}{ Country } & \multicolumn{4}{|c|}{ Retail sales } & \multicolumn{2}{|c|}{$\begin{array}{l}-/+ \text { in } \% \text { in } 2015 \\
\text { compared to } 2010\end{array}$} \\
\hline & \multicolumn{2}{|c|}{2015} & \multicolumn{2}{|c|}{2010} & \multirow{2}{*}{$\begin{array}{l}\text { Retail } \\
\text { sales }\end{array}$} & \multirow{2}{*}{$\begin{array}{c}\text { Retail } \\
\text { sales per } \\
\text { capita }\end{array}$} \\
\hline & $\begin{array}{c}\text { Million } \\
\text { Euro }\end{array}$ & $\begin{array}{l}\text { Euro / } \\
\text { person }\end{array}$ & $\begin{array}{c}\text { Million } \\
\text { Euro }\end{array}$ & $\begin{array}{l}\text { Euro / } \\
\text { person }\end{array}$ & & \\
\hline Austria & $1065^{b)}$ & $127^{\mathrm{b})}$ & 986 & 117,8 & & \\
\hline Belgium & 514 & 45,7 & 421 & 38,8 & 22,1 & 17,8 \\
\hline Bulgaria & n.d. & n.d. & 7 & 0,9 & & \\
\hline Croatia & $99^{\text {d) }}$ & $23,4^{\text {d) }}$ & 69,2 & 15,6 & $43,1^{\mathrm{e})}$ & $50,0^{\mathrm{e})}$ \\
\hline Czech Republic & $74^{\mathrm{d})}$ & $7^{\text {d) }}$ & 59 & 7,4 & $25,4^{\mathrm{e})}$ & $-5,4^{\mathrm{e})}$ \\
\hline Denmark & 1079 & 190,7 & 791 & 142,2 & 36,4 & 34,1 \\
\hline Estonia & n.d. & n.d. & $11,8^{a)}$ & $8,8^{\text {a) }}$ & & \\
\hline Finland & 240 & 43,9 & 80 & 14,9 & 200,0 & 194,6 \\
\hline France & 5534 & 83,3 & 3385 & 52,3 & 63,5 & 59,3 \\
\hline Germany & 8620 & 105,9 & 6020 & 73,1 & 43,2 & 44,9 \\
\hline Greece & n.d. & n.d. & 60 & 5,3 & & \\
\hline Hungary & 30 & 3 & $25^{\text {a) }}$ & $2,5^{\text {a) }}$ & $20,0^{f)}$ & $20,0^{f)}$ \\
\hline Ireland & 142 & 30,7 & 103,2 & 23,1 & 37,6 & 32,9 \\
\hline Italy & 2317 & 38,1 & 1550 & 29,8 & 49,5 & 27,9 \\
\hline Latvia & $4^{b)}$ & $2^{\mathrm{b})}$ & n.d. & n.d. & & \\
\hline Lithuania & $6^{\mathrm{b})}$ & $2^{b)}$ & n.d. & n.d. & & \\
\hline Luxembourg & 94 & 170 & 65 & 127,5 & 44,6 & 33,3 \\
\hline Netherlands & 1072 & 63,4 & 656,5 & 39,6 & 63,3 & 60,1 \\
\hline Poland & 167 & 4,4 & 58,9 & 1,5 & 183,5 & 193,3 \\
\hline Portugal & $21^{b)}$ & $2^{b)}$ & 21 & 2,1 & & \\
\hline Romania & $80^{b)}$ & $3,7^{b)}$ & 45 & 2,1 & & \\
\hline
\end{tabular}




\begin{tabular}{|c|c|c|c|c|c|c|} 
Slovakia & n.d. & n.d. & 4 & 0,7 & & \\
\hline Slovenia & $49^{\text {c) }}$ & $26,6^{\text {c) }}$ & 38 & 18,6 & & \\
\hline Spain & 1498 & 32,3 & $905^{\text {a) }}$ & $19,5^{\text {a) }}$ & $65,5^{\text {f) }}$ & $65,6^{\text {f }}$ \\
\hline Sweden & 1726 & 177,1 & 803,8 & 86,1 & 114,7 & 105,7 \\
\hline United Kingdom & 2604 & 40,2 & 2000 & 32,2 & 30,2 & 24,8 \\
\hline $\begin{array}{c}\text { European Union } \\
\text { (28 countries) }\end{array}$ & $\mathbf{2 7 1 0 7}$ & $\mathbf{5 3 , 7}$ & n.d. & n.d. & & \\
\hline Europe & $\mathbf{2 9 7 8 1}$ & $\mathbf{3 6 , 4}$ & n.d. & n.d. & & \\
\hline
\end{tabular}

$$
\text { n.d. - no data }
$$

Dynamics was calculated for periods of at least 4 years

${ }^{\text {a) }}$ Data for 2009; ${ }^{\text {b) }}$ Data for 2011; ${ }^{\text {c) }}$ Data for 2013; ${ }^{\text {d) }}$ Data for 2014; ${ }^{\text {e) }}-/+$ in \% in 2014 compared to $2010^{\text {f) }}$ $-/+$ in $\%$ in 2015 compared to 2009 ;

Source: taking over and processing after FiBL-AMI survey 2017, in Willer, Helga and Julia Lernoud (Eds.)

(2017): The World of Organic Agriculture, Statistics and Emerging Trends 2017. Research Institute of

Organic Agriculture (FiBL), Frick and IFOAM - Organics International, Bonn. Version 1.3 of February 20, 2017 (Table 66);

FiBL survey 2012, in Willer, Helga and Lukas Kilcher (Eds.) (2012): The World of Organic Agriculture, Statistics and Emerging Trends, 2012. FiBL-IFOAM Report. Research Institute of Organic Agriculture

(FiBL), Frick and IFOAM, (Table 58).

Analyzing the dependence between average spending per capita and Gross Domestic Product at market prices in some of the EU countries for which we have data, we see a direct link; of the average expenditure variation in the 16 countries surveyed, almost $50 \%$ being determined by the Gross Domestic Product variation. Note that by checking the statistical significance of the relationship between the two variables with the Fisher test, it was found that this is significant for a significance level of 5\%. (Table 6 and Figure 2).

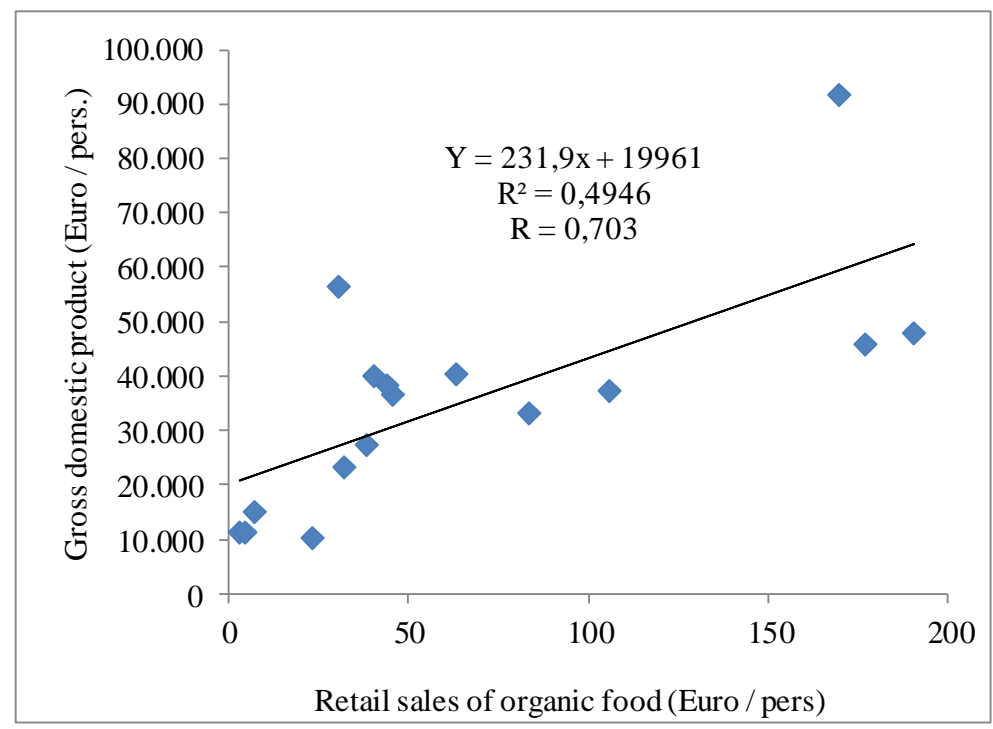

Figure 2. Relationship between retail sales of organic food (Euro/pers) si Gross domestic product at market prices (Euro/pers) in some UE countries* in 2015

*Belgium, Croatia, Czech Republic, Denmark, Finland, France, Germany, Hungary, Ireland, Italy,

Luxembourg, Netherlands, Poland, Spain, Sweden, United Kingdom, for which we have data. For Croatia and Czech Republic, data is for 2014.

Source: adapted after FiBL-AMI survey 2017 (for data regarding retail sales of organic food) and Eurostat, 2018 for Gross domestic product at market prices 
Table 6. Relationship between retail sales of organic food (Euro/pers) si Gross domestic product at market prices (Euro/pers) in some EU countries* in 2015

\begin{tabular}{|c|c|c|c|c|c|c|}
\hline Countries & $\begin{array}{c}\text { Regression } \\
\text { equation }\end{array}$ & $\begin{array}{c}\text { Coefficient of } \\
\text { determination } \\
\left(\boldsymbol{R}^{2}\right)\end{array}$ & $\begin{array}{c}\text { Correlation } \\
\text { coefficient } \\
(\boldsymbol{r})\end{array}$ & $\begin{array}{c}\text { Calcula } \\
\text { ted } \boldsymbol{F} \text { - } \\
\text { Value }\end{array}$ & $\begin{array}{c}\text { Signific } \\
\text { ance } \\
\text { level }\end{array}$ & $\begin{array}{c}\text { Theoretic } \\
\text { al } \boldsymbol{F} \text { - } \\
\text { Value }\end{array}$ \\
\hline $\begin{array}{c}\text { European } \\
\text { Union } \\
(\mathrm{EU}-28)\end{array}$ & $\begin{array}{c}\mathrm{Y}=231.9 \mathrm{x}+ \\
19961\end{array}$ & 49.46 & 0.703 & 13.7 & 0.01 & 8.86 \\
\hline
\end{tabular}

*Belgium, Croatia, Czech Republic, Denmark, Finland, France, Germany, Hungary, Ireland, Italy, Luxembourg, Netherlands, Poland, Spain, Sweden, United Kingdom, for which we have data. For Croatia and Czech Republic, data is for 2014.

Source: adapted after FiBL-AMI survey 2017 (pentru datele privind retail sales of organic food) and Eurostat, 2018 for Gross domestic product at market prices

Although characterized by a rapid growing, population consumption of organic food remains at a low level. For example, in Denmark, the country with the highest level of organic spending at EU level, in 2015, the share of organic food in total food sales in retail stores was estimated (Ekoweb estimates) at just $8.3 \%$. However, it is worth noting that this share is increasing, in 2010 the indicator was 5.7\%. (Statista, 2018). Also, in the same year, in Germany (another country for which we have data) organic share of the total food market was $4.78 \%$ (http://orgprints.org, 2018).

There are many reasons behind the limitations in the growth of the organic product market. Thus, according to the study published in Denmark, Italy and the United Kingdom by Jensen, K., Denver, S., Zanoli, R. (2011), with data for 2006 and 2007, some of the reasons behind the slow increase in demand for organic products are:

- (higher) prices for some of these products, but also the poor or even the nonexistence of organic products for certain categories of food; (barriers for those who regularly consume organic products);

- lack of confidence in organic farmers, low importance for healthy eating and / or lack of knowledge of organic food (barriers to the occasional or nonconsumers of organic products).

Strengthening the last idea presented, the study carried out in 6 European countries by Zander, K., Padel S., Zanoli R. (2015) shows a low level of knowledge of the European ecological logo (introduced in 2010); of the total of 3,000 respondents, only $15 \%$ of them knowing the significance of that logo.

It is obvious that in the absence of knowledge of the benefits of organic products consumption and / or their recognition (via the logo), the possibilities for extensive market growth are practically limited.

\section{Conclusions}

Responding to the orientation of more and more consumers to a healthy diet, the EU organic food market has seen a positive development in recent years. However, the statistical data shows that the average consumption per capita for this product category is kept at a low level, with a huge potential for development now. Starting from the results of an EU study (presented above) that identified many factors justifying the relatively low consumption of organic food, we can appreciate that the diversification of the range, the intensification of the media coverage of the characteristics of these products and their impact on health and finding solutions for price hikes are lines of action with potential effect in the expansion of this market. 


\section{References}

Harja E., Ţimiraş L.C. (2009), Metode statistice utilizate în cercetarea de marketing, Bacau, Editura Alma Mater

Helga, W., Lernoud, J., (Eds.) (2017): The World of Organic Agriculture, Statistics and Emerging Trends 2017. Research Institute of Organic Agriculture (FiBL), Frick and IFOAM - Organics International, Bonn. Version 1.3 of February 20, 2017, available

at: https://shop.fibl.org/CHen/mwdownloads/download/link/id/785/?ref=1

Helga, W. and Kilcher, L. (Eds.) (2012): The World of Organic Agriculture, Statistics and Emerging Trends, 2012. FiBL-IFOAM Report. Research Institute of Organic Agriculture (FiBL), Frick and IFOAM, available at: https://shop.fibl.org/CHde/mwdownloads/download/link/id/785/?ref=1

Lohr, L. (1998), Implications of Organic Certification for Market Structure and Trade, American Journal of Agricultural Economics, 80 (Number 5, 1998), pp 11251129, available at: http://www.jstor.org/stable/1244216

Jensen, K., Denver, S., Zanoli, R. (2011), Actual and potential development of consumer demand on the organic food market in Europe, NJAS - Wageningen Journal of Life Sciences, Volume 58, Issues 3-4, December 2011, Pages 79-84, available at: https://www.sciencedirect.com/science/article/pii/S1573521411000066

Zander, K., Padel S., Zanoli, R. (2015), EU organic logo and its perception by consumers, British Food Journal, Volume: 117, Issue: 5, 2015, available at: https://www.emeraldinsight.com/doi/full/10.1108/BFJ-08-2014-0298

Agricultural Market Information Company (AMI) (2017), The organic market in Germany-highlights 2016, Diana Schaack,, Biofach, Nürnberg (available at: http://orgprints.org/31200/7/schaack-2017-organic-market-germanybiofach2017.pdf)

Council Regulation EC No. 834/2007 on organic production and labelling of organic products, available at: https://eur-lex.europa.eu/legalcontent/EN/TXT/?uri=CELEX\%3A32007R0834

Eurostat, 2018, available at: http://ec.europa.eu/eurostat

Statista Inc. (2018), available at: https://www.statista.com 